University for Business and Technology in Kosovo

UBT Knowledge Center

UBT International Conference

2017 UBT International Conference

Oct 28th, 11:00 AM - 12:30 AM

\title{
Process of Decentralization in the Republic of Kosovo
}

Agni Aliu

University for Business and Technology, agni.aliu@ubt-uni.net

Artan Tahiri

University for Business and Technology, artan.tahiri@ubt-uni.net

Follow this and additional works at: https://knowledgecenter.ubt-uni.net/conference

Part of the Law Commons

\section{Recommended Citation}

Aliu, Agni and Tahiri, Artan, "Process of Decentralization in the Republic of Kosovo" (2017). UBT International Conference. 220.

https://knowledgecenter.ubt-uni.net/conference/2017/all-events/220

This Event is brought to you for free and open access by the Publication and Journals at UBT Knowledge Center. It has been accepted for inclusion in UBT International Conference by an authorized administrator of UBT Knowledge Center. For more information, please contact knowledge.center@ubt-uni.net. 


\title{
Process of Decentralization in Republic of Kosova
}

\author{
Agni Aliu, Artan Tahiri \\ UBT-Institution of Higher Education \\ $\left\{\right.$ agni.aliu ${ }^{1}$; $\left.\operatorname{artan}_{\text {tahiri }}{ }^{2}\right\} @$ ubt-uni.net
}

\begin{abstract}
The subject of the study in this paper is the process of decentralization in the Republic of Kosovo and the obstacles faced.The Republic of Kosovo is one of the world's newest states, so it is natural to face a host of complex problems with Local Government in general, while special attention should be paid to the process of decentralization. The Decentralization process should be well-analyzed by comparing with notions such as: Local Governance and its Basic Characteristics, Democracy, Centralization, Deconcentration, etc. This process implies the transfer of competencies, from central government organs to a certain degree of local government organs. Given the fact that local government is involved, the Republic of Kosovo as a New State should, through a proper strategy, make decentralization (transfer of competencies) from central government organs to local government organs, especially in the areas covered by the local governance. The process of decentralization in the Republic of Kosovo faces a lot of difficulties, such as the lack of a strategy for the implementation of this process, the lack of financial means, the lack of administrative staff, the lack of modern information technology tools, lack of a proper political situation, etc. .
\end{abstract}

Key words: Local government, Democracy, Decentralization, Centralization, Deconcentration.

\section{Interduction}

For better understanding of decentralization, we need to study the relations with some notions such as: local governance, centralization, deconcentration, etc.

Decentralization and local governance are in such a ratio that in theory and practice is very difficult to clearly define in order to pull the boundary between them. The main reason is that with decentralization in the general sense, as well as with local government, is meant any "anticentralism".

In every decentralization there are elements of local government, just as there are signs of decentralization in every local government. However, the distinction between local government and decentralization should be distinguished, both theoretically and in practical terms.

Decentralization is largely a "system between central and local organs in which local authorities have a certain independence". The limits of this independence are usually set by law, but sometimes are foreseen by the constitution as well.

According to the constitutional and legal definitions, local authorities are independent during their actions, while central organs, as a rule, have no other right than to oversee the legality of the work of local authorities. 
Decentralization, as a notion, means "transferring certain functions from central organs to local authorities"78.

Central organs exercise control of the legality of the work of local organs, but not control of their opportunity.

Local authorities are at a lower level than the central organs, so central organs behave like tutors to them.

Decentralization is an administrative notion and category of administrative law.

Local government has constitutional status, as it is defined and guaranteed by the constitution. Therefore, the right of self-administration is counted as a category of constitutional right, but also of the political system at the same time.

The report on local governance and decentralization in contemporary conditions is manifested "in the forefront of two opposing processes". On the one hand, we face the original character of power decentralization, while, on the other hand, we encounter the process of losing the original character of local government and all governance is considered to be the "creation of central government".

The elements of decentralization of local governance are presented in several main types:

A. The local government is presented as an element of decentralization, with legal and administrative status and with a host of independent authorizations;

B. Local government, with the preservation of independence and self-government in the territory of the local community that performs and some central functions;

C. Local government, with organic and legal combination of elements of self-administration, decentralization, and even centralization;

In contemporary states, the interest in local government is growing. This interest is particularly evident in the former socialist bloc states in the states that started the path of building a democratic political system ${ }^{79}$.

\section{Decentralization Report with Centralization}

The Republic of Kosovo as one of the newest states in the world should initially have to build state central organs and other institutions. Centralization represents the concentration of power in a center and the exercise of total control over the lower organs. Central organs face problems of large volumes of their scope, so there is a need to dislocate a large number of competences to those of the local character. Because of the citizens are concerned that the fulfillment of the needs of a local character be done independently as close to yourself and at a lower cost.

${ }^{78}$ Saliu, Kurtesh: E drejta kushtetuese Libri I, Prishtinë, 2002, fq. 263.

${ }^{79}$ Djordjević, Jovan: Politički sistem, Beograd, 1988, fq. 536-537. 


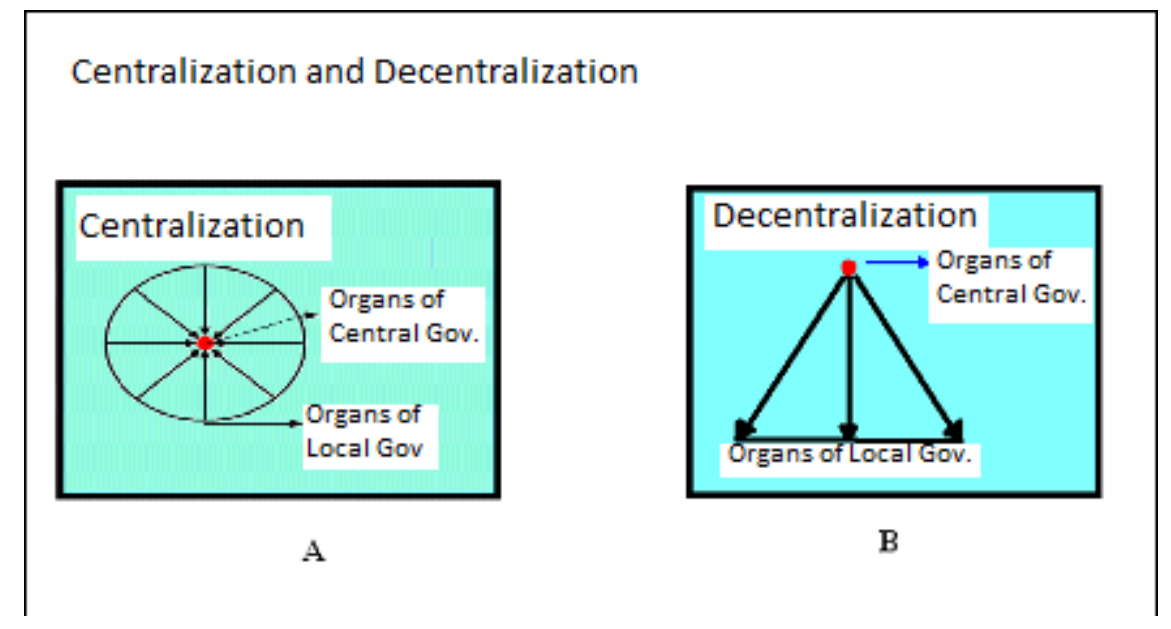

Fig.1 - Centralizimi dhe decentralizimi

\section{Decentralization Report with Deconcentration}

Deconcentration represents only "technical and administrative form of centralization that reflects the fundamental difference with decentralization". Organs that exist and act in the process of deconcentration are always appointed by the central organs, while their acts are subject to the control of legality and of the opportunity. On the contrary, in the decentralization process, local authorities are solved by the citizens themselves, then the central authorities only control the legality and not the opportunity.

Decentralization represents a higher form of democratization of the territorial organization of the state.

\section{Decentralization Report with Regionalization}

The notion of the region has many dimensional meanings: geographical, political - territorial, economic, sociological and legal.Usually, the region is taken as a spatial, adequate and capable of economic, political and institutional development, with a certain degree of independence in relation to the state power expressed through "self-organization, competencies and funding".

Regionalization as a process of creating decentralized territories of ethnicities and regions in the aforementioned sense is widespread, both in unitary and composite states.In literature we come across many of the terms in which the region emerges.In the political-territorial sense, the region is a socio-economic and political whole closer than federal units and autonomous entities. The region is broader than the basic territorial units. The main purpose of regionalization is to "limit centralization, not to allow cultural and political monopolization". Regionalization enables faster development.Contemporary regionalism appears in France in the $18^{\text {th }}$ century, as a "process directed 
against concentration and enormous centralization of capital production, administration and culture".We live in the time of European integration. The integration process challenges the independent national states, while favoring the regions as a whole economic and cultural, directed towards supranational communities.

Regionalization enables the participation of different cultural communities unlike federalism where national independence is expressed. Future Europe will no doubt be "community of regions" and not "community of states".

The decentralization process in the Republic of Kosovo develops under difficult circumstances from liberation to the present. It was initially regulated by UNMIK Regulation 2000/45. Unfortunately, the process of decentralization in the Republic of Kosovo is confused with the territorial administrative division that still poses a problem for the creation of a proper strategy for the decentralization process. Territorial division is one of the basic features of local governance, but not decentralization process. It can have a positive impact if we take into account several factors: the territory of local government units, the number of population, gravitation to a given center, infrastructure, natural and human resources, made by a team of experts in relevant fields.

The Republic of Kosovo from liberation to today has increased the number of municipalities but this is a territorial division rather than a process of decentralization.

Special attention should also be paid to the competencies of the local government units in the Republic of Kosovo for the fact that there are three types of competencies:

1. Own competencies (independent),

2. Delegated powers,

3. Enhanced competencies

Decentralization is the dislocation (transfer) of competencies from central government organs to local government organs.

\section{Conclusions}

In order to speed up the decentralization process in the Republic of Kosovo, it should initially:

- develop a decentralization strategy,

- Provide sources of financial resources,

- it must be a territorial division of truth,

- there should be good will for local government cooperation

- have a staff of relevant experts,

- have access to contemporary information technology,

\section{References}

1. Aliu, Agni \& Stavileci Esat: Qeverisja Lokale, Njoftime themelore dhe shqyrtime krahasimtare, Tetove - Prishtine, 2009

2. Saliu, Kurtesh: E drejta kushtetuese Libri I, Prishtinë, 2002, fq. 263.

3. Djordjević, Jovan: Politički sistem, Beograd, 1988, fq. 536-537.

4. Karta Evropiane per Veteqeverisje Lokale, Strazburg, 1985. 
5. Ligji per Veteqeverisje Lokale i R.K -se, 2008. 